\title{
Importance of the portal venous pathway to the transport of intestinal triglyceride-rich lipoproteins in the preruminant calf
}

\author{
D Durand1', D Bauchart1, PM Laplaud2,3, J Lefaivre4, MJ Chapman3 \\ 'Laboratoire d'Etude du Mótabolisme Energétique, INRA Theix, 63122 St-Genes Champanelle; \\ 2 Laboratoire de Biochimie Médicale, Faculté de Médecine et de Pharmacie, \\ 87025 Limoges Cedex; ${ }^{3}$ Unité de Recherches sur les Lipoprotéines et l'Athérogenèse, \\ (INSERM U321), Hôpital de la Pitié, 75651 Paris Cedex 13; 4 Unité de la Dynamique de la Digestion, \\ INRA Theix, 63122 St-Genes Champanelle, France
}

It is generally accepted that intestinal triglycerides are secreted into lymphatics mainly as chylomicrons (CM) but also as very-low density lipoproteins (VLDL). In the preruminant calf, we recently observed the presence of triglyceride-rich particles $(d<1.018 \mathrm{~g} / \mathrm{ml})$ in portal venous blood (Bauchart et al, 1989). In order to evaluate the contribution of the portal vein to the transport of intestinal VLDL and CM, two 3 wk old Friesian male calves $(51 \pm 4 \mathrm{~kg}$; $650 \mathrm{~g} / \mathrm{d}$ body weight gain) were equipped with 3 chronic cannulae (portal vein (PV), mesenteric artery (MA) and intestinal lymph duct (ILD)) and an electromagnetic flow probe (PV). The animals were fed a milk substitute (22\% tallow, $23 \%$ protein) twice daily. On the day of the experiment, the animals were given the morning meal only. Blood and lymph samples were then collected 3,8 and $16 \mathrm{~h}$ after feeding. $\mathrm{CM}$ and VLDL were isolated by ultracentrifugal flotation. Total intestinal production (PV + ILD - MA) of CM amounted to about $4 \mathrm{~g} / \mathrm{h}$ at peak absorption of lipids ( $8 \mathrm{~h}$ after a meal) but only $1.3 \mathrm{~g} / \mathrm{h}$ some $8 \mathrm{~h}$ later (table 1). The same kinetics were observed for VLDL. Under these conditions, we observed an important and significant contribution of the portal vein (PV/(PV + ILD) $x$ $100)$ to lipid transport principally at peak absorption for CM $(67 \%)$ and at the 3 time points for VLDL $(50-80 \%)$. These results might be partially due to a slow intestinal lipid absorption such as occurs in the preruminant calf fed a milk diet which coagulates in the abomasum. Indeed, as has been previously shown in the rat, a slow infusion of long-chain fatty acids into the duodenum leads to a preferential transport of these acids $(60-70 \%)$ in the portal vein.

Bauchart D, Durand D, Laplaud PM, Forgez P, Goulinet S, Chapman MJ (1989) J Lipid Res $30,1499-1514$

Table I. Contribution of the portal vein to the intestinal production of chylomicrons and VLDL in the calf $(n=2)$.

Chylomicrons

$V L D L$

\begin{tabular}{lcccccc} 
Hours after meal & 3 & 8 & 16 & 3 & 8 & 16 \\
Total intestinal production $(\mathrm{g} / \mathrm{h})$ & 3.6 & 4.2 & 1.3 & 5.1 & 17.3 & 2.1 \\
Portal contribution (\%) & 41 & 67 & 20 & 51 & 58 & 80 \\
\hline
\end{tabular}

